\title{
Technologies for lake restoration
}

\author{
Helmut KLAPPER \\ UFZ Centre for Environmental Research Leipzig-Halle, Dept Inland Water Research, Brückstraße 3a, D-39114 Magdeburg, \\ Germany \\ e-mail: Klapper@gm.ufz.de
}

\begin{abstract}
Lakes are suffering from different stress factors and need to be restored using different approaches. The eutrophication remains as the main water quality management problem for inland waters: both lakes and reservoirs. The way to curb the degradation is to stop the nutrient sources and to accelerate the restoration with help of in-lake technologies. Especially lakes with a long retention time need (eco-) technological help to decrease the nutrient content in the free water. The microbial and other organic matter from sewage and other autochthonous biomasses, causes oxygen depletion, which has many adverse effects. In less developed countries big reservoirs function as sewage treatment plants. Natural aeration solves problems only partly and many pollutants tend to accumulate in the sediments. The acidification by acid rain and by pyrite oxidation has to be controlled by acid neutralizing technologies. Addition of alkaline chemicals is useful only for soft waters, and technologies for (microbial) alkalinization of very acidic hardwater mining lakes are in development. The corrective measures differ from those in use for eutrophication control. The salinization and water shortage mostly occurs if more water is used than available. L. Aral, L. Tschad, the Dead Sea or L. Nasser belong to waters with most severe environmental problems on a global scale. Their hydrologic regime needs to be evaluated. The inflow of salt water at the bottom of some mining lakes adds to stability of stratification, and thus accumulation of hydrogen sulphide in the monimolimnion of the meromictic lakes. Destratification, which is the most used technology, is only restricted applicable because of the dangerous concentrations of the byproducts of biological degradation. The contamination of lakes with hazardous substances from industry and agriculture require different restoration technologies, including subhydric isolation and storage, addition of nutrients for better self-purification or anaerobic technologies, to eliminate the pollutant nitrate by microbial denitrification. The retention time is an important parameter for modellers and limnologists, that allows them to decide, which technologies - hydromechanical, chemical or biological - have to be applied alone or in combination to cope best with each specific problem. The technologies have to be economical and ecological safe.
\end{abstract}

Key words: lake degradation, lake restoration, restoration technologies, residence time, recovery

\section{INTRODUCTION}

Lakes, both natural or man-made suffer from urban, industrial, agricultural and other impacts. As a result, many aquatic ecosystems have become severely degraded and need to be restored. In many countries, large sums of money now being spent to restore such lakes (Allan 1997). The last three decades good experience and expertise has increased worldwide. But the high investments, that are needed demand for a more scientific and sustainable ecosystem management, i.e. to restore the degraded lake to a level, that can be permanently sustained through protection and conservation. The water-quality target should be in accordance with quality of natural waters, and without the stresses, that cause degradation, i.e. with a good ecosystem health, longterm stability and sustainability. Such conditions prevailed in the pre-industrial time. In the drainage basins of the lakes the organic matter production has now dramatically increased because of the intensive use of nutrients $(\mathrm{N}, \mathrm{P})$ by the agriculture in the lake catchment areas, the industrialisation and the growth of the population density. A good orientation about the pre-industrial status may be gained with help of paleolimnological investigations. Deeper layers contain fossils of more sensitive indicator organisms and the thickness of the yearly sediment layer is growing.

The time needed to achieve the restoration target is longer than one would expect on basis of some existing models: it depends first of all from residence time (RT) and is included in most models applied (Imboden \& Gaechter 1978). In many shallow lakes the phosphorus accumulated in the sediments and/or an unsuitable food web delays the effects of the restoration measures (Sondergaard et al. 2001; Sas et al. 1989).

In Lake Constance P-concentrations decreased following external reductions, and which phytoplankton production decreased, after a delay of 10 to 15 years. The long delay compared with only 4 years RT is assumed to be because of adaptation needed by the biocoenoses to the new abiotic conditions (Gaedke 1998; Guede et al. 2000).

Water quality management of lakes and reservoirs was first oriented to control eutrophication and the factors causing increase of nutrient load (Tab. 1). Many solutions are now available to control eutrophication by minimizing the nutrient inflows. But often organic loads, acidity, salinity or contamination with hazardous substances need to be controlled. The amendment of the conditions may be very different, in some cases contrary to the technologies developed to control eutrophication. 
Tab. 1. Main stress factors, demanding restoration activities on and in lakes.

\begin{tabular}{|c|c|c|}
\hline lake ecosystem stresses & main reasons & consequences for the ecosystem \\
\hline eutrophication & $\begin{array}{l}\text { nutrient load from point sources } \\
\text { nutrient load from diffuse sources }\end{array}$ & $\begin{array}{l}\text { unwanted high plant growth, algae blooms, fish } \\
\text { kills (very numerous) }\end{array}$ \\
\hline $\begin{array}{l}\text { saprobization } \\
\& \text { microbial infection }\end{array}$ & $\begin{array}{l}\text { BOD-load from: } \\
\text { - anthropogenic sources (sewage) } \\
\text { - natural sources (e.g.humic matter } \\
\text { from rewetting of bogs) } \\
\text { - autochthonous biomass }\end{array}$ & $\begin{array}{l}\text { oxygen depletion, fish kills, (Barra Bonita, Upper } \\
\text { Saale Reservoir, L. Rudower See) }\end{array}$ \\
\hline acidification & $\begin{array}{l}\text { acid rain with } \mathrm{SO}_{2} \text { and } \mathrm{NO}_{x} \\
\text { geogenic sulfur acidification from pyrite oxidation }\end{array}$ & $\begin{array}{l}\text { low } \mathrm{pH} \text {, metal load, absence of hydrogen } \\
\text { carbonate, low species diversity (soft water lakes } \\
\text { in the primary rocks, mining lakes) }\end{array}$ \\
\hline salinization & $\begin{array}{l}\text { transpiration losses by irrigation } \\
\text { transpiration losses by big surface } \\
\text { connections to salt layers }\end{array}$ & $\begin{array}{l}\text { decreased size of lake (Aral,Tschad) } \\
\text { decrease of the throughflow (Nile, L. Nasser), } \\
\text { meromixis in mining lakes (L. Merseburg-east) }\end{array}$ \\
\hline contamination & $\begin{array}{l}\text { hazardous substances: industrial wastes; nitrate or } \\
\text { pesticides from agriculture }\end{array}$ & $\begin{array}{l}\mathrm{O}_{2} \text {-depletion, insufficient self-purification (L. } \\
\text { Orta, Zeulenroda Reservoir) }\end{array}$ \\
\hline
\end{tabular}

Tab. 2. Control of the nutrient export from the drainage basin and the nutrient import into the lakes

\begin{tabular}{|c|c|}
\hline Measures & Examples \\
\hline $\begin{array}{l}\text { Point sources } \\
\text { 1. Diversion of sewage from the drainage basin. } \\
\text { 2. Rational water use with recirculation and use of the } \\
\text { secondary raw materials. } \\
\text { 3. Sewage treatment with nutrient elimination or nutrient } \\
\text { utilization. }\end{array}$ & $\begin{array}{l}\text { Ring sewerage systems and purification plants downstreams } \\
\text { the lakes are typical restoration approaches for many alpine } \\
\text { lakes. } \\
\text { Sugar factories with full recirculation do'nt produce wastes. } \\
\text { In Germany all treatment plants }>20000 \text { inhabitant } \\
\text { equivalents are to be equipped with nutrient elimination } \\
\text { steps. }\end{array}$ \\
\hline $\begin{array}{l}\text { Nonpoint sources } \\
\text { 4. Afforestation of erosion-endangered steep slopes. } \\
\text { 5. Establishment of protecting zones and adapted agricultural } \\
\text { practice. } \\
\text { 5.1. Soil utilization and hydromelioration with minimal } \\
\text { nutrient losses. } \\
\text { 5.2. Fruit sequences with intercropping, permanent } \\
\text { vegetation cover. } \\
\text { 5.3. Fertilizing according to plant demand (kind, amount } \\
\text { and time). } \\
\text { 5.4. Soil treatment (ploughing, harrowing, sowing ...) } \\
\text { parallel to the slope. }\end{array}$ & $\begin{array}{l}\text { Protecting zones with rules for performing land use with } \\
\text { minimized nutrient losses are standard at drinking water } \\
\text { reservoirs and exemplary for all lakes. }\end{array}$ \\
\hline $\begin{array}{l}\text { Barriers for nutrient entry to the lake } \\
\text { 6. Protecting forest belts along the inflowing rivers. } \\
\text { 7. Prebasins with crown overflow for nutrient elimination. } \\
\text { 8. Extraction by macrophytes. } \\
\text { 9. Phosphorus elimination plant (PEP) at the main inlet. }\end{array}$ & $\begin{array}{l}\text { The belt functions as a buffer system. Harvest without } \\
\text { fertilizing curbs the output to the water bodies. } \\
\text { About } 50 \% \text { of the incoming P does not reach the main } \\
\text { reservoir. } \\
\text { Inlet "bioplateaus", wetlands with harvest } \\
\text { PEP are in operation at Wahnbach Reservoir, Tegeler See, } \\
\text { Schlachtensee, Ulmener Maar, Süsser See }\end{array}$ \\
\hline
\end{tabular}

\section{CONTROL OF EUTROPHICATION}

\subsection{Curbing the nutrient import into a lake}

The prophylaxis against eutrophication includes the socio-political tools for water quality management. They make use of the legal options for protecting the water body from harmful impacts, using statutory regulations that the lakes and their catchment can be controlled on a long-term planned basis to prevent the need for more costly clean-up measures. Thus "prophylaxis"

has the highest priority, followed by activities for maintenance of a healthy state in which the nutrients are detained to prevent their entering the water body (Tab. 2).

The point sources reduction of phosphorus has been achieved using high level of technologies. In Germany inland lakes are now protected against nutrient load but also the seas North, Baltic and Black Sea. All sewage plants larger than 20,000 inhabitant equivalents are equipped with nutrient elimination facilities according to state regulations. In the alpine region the main measure used against eutrophication is $3^{\text {rd }}$ step sewage treat- 


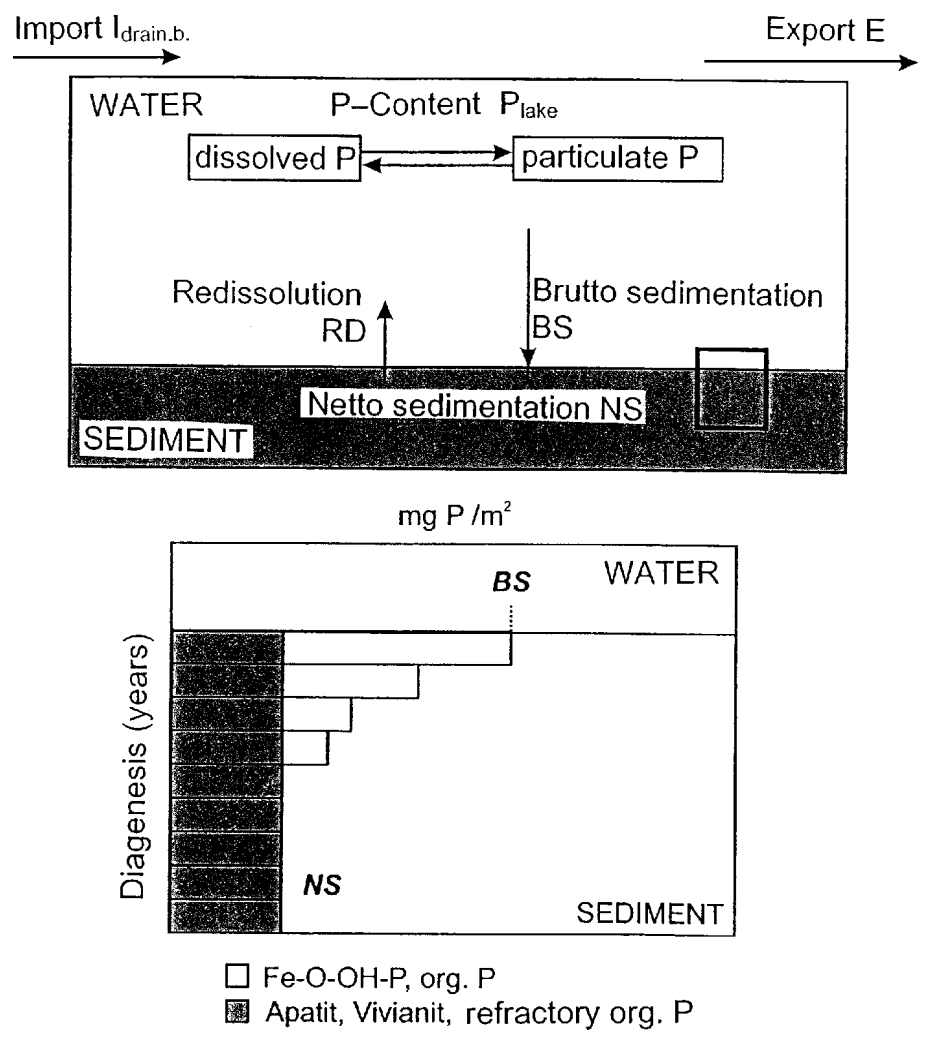

Fig. 1. Outline of the phosphorus balance in a lake (modified from Hupfer \& Scharf 2002)

ment plant or biological group treatment plant downstream of the protected lake. All nutrient point sources are diverted to these plants. Together with phosphorusfree detergents all measures are directed at minimizing the growth-limiting nutrient and for which impressive results are achieved, even in many big lakes, as e.g. Lake Constance, Zürichsee, Lago Maggiore, Ossiacher See, Lake Geneva (Sas et al. 1989).

In aridic climates there is often not enough water to be diverted. It has to be stored for re-use and control of eutrophication is achieved by in-lake measures. Thousands of service ecosystems have been built in Israel, South Africa etc. for self-purification. The oxygen produced by algal photosynthesis is used for degradation of organic pollutants. In addition to the use of treated water for irrigation, the groundwater is replenished by artificial enrichment. Hence, water re-use in such countries with limited water resources is quite usual.

Nonpoint sources of nutrient inflow to lakes are mainly caused by farming in the drainage basins. Agricultural soils are fertilized, irrigated, drained, to increase the bioproduction, the lakes in the same basin have to be kept on a low level of productivity. Therefore, buffer ecosystems are useful between agricultural and water areas. The predams at nearly all new drinking water reservoirs in Germany have to be operated with several days retention time (RT). Therefore, with inlet barriers and underwater walls the inflowing water is mixed into the whole volume to get as near as possible to the theo- retical RT. From the predams the water is diverted by crown overflows to the main reservoirs, to make use of the vertical concentration gradient (Benndorf \& Pütz 1987). Similar effects may be gained with natural or mining lakes, situated in chains along a river system. Upstream lakes also act as "prebasins" for water bodies situated downstream. The efficiency of the elimination of particulate matter may be increased with help of sedimentation traps and macrophytic biofilters in outlet and inlet reaches of the different "links" of the chain.

In several water bodies in Germany, eutrophication is controlled with the help of phosphorus elimination plants (PEP) such as at the main inlet of Wahnbach Reservoir, Lakes Tegeler See and Schlachtensee in Berlin, Ulmener Maar and Suesser See (Bernhardt \& Clasen 1985; Chorus 1995; Scharf 1995; Scheffer et al. 1999). These PEP have to be adapted to the hydrologic regime. At the PEP Suesser See a P-removal of $>90 \%$ elimination has been achieved. But during high floods when erosion is high, the overall P-removal decreases to only 40\% (Scheffer et al. 1999). At Schlachtensee and Tegeler See the chlorophyll content decreased significantly, after the TP concentration decreased to $<50$ to 60 $\mu \mathrm{gl}^{-1}$; success at the PEP at Tegeler See was reached after 9 years of operation (Chorus 1995). In addition the P-content of a lake may be decreased by increasing exports to the outflow or by immobilization in the sediments (Fig. 1). 
Selective take-off

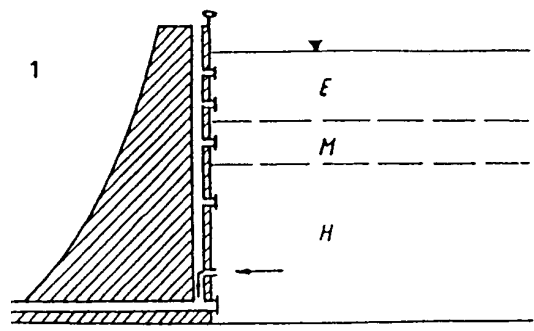

Selective take-off by use of outlets at different depths in a modern reservoir
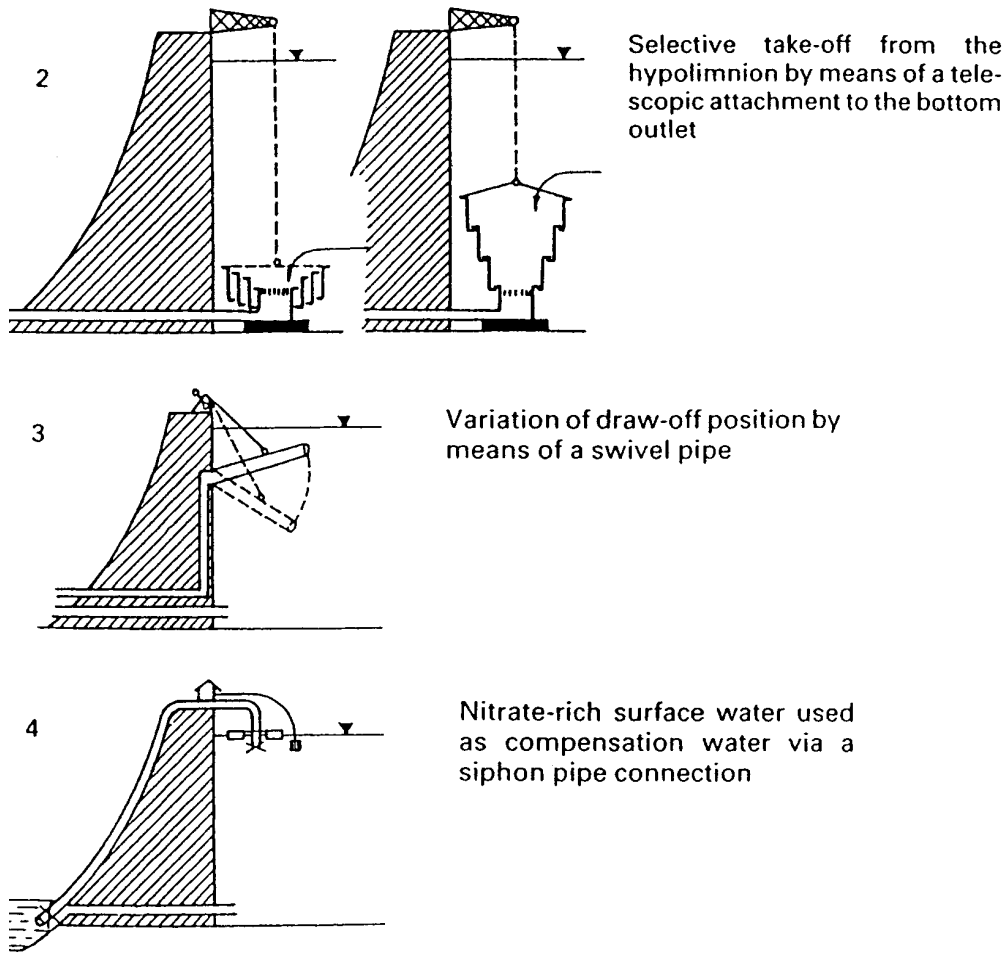

Nitrate-rich surface water used as compensation water via a siphon pipe connection

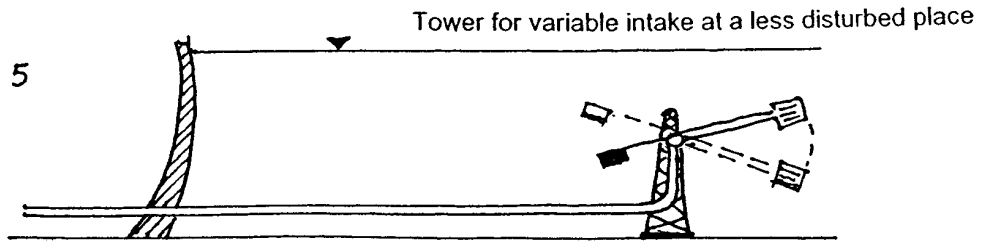

Fig. 2. Water quality control in reservoirs by selective off-take (Klapper 1991).

\subsection{Increasing the nutrient export}

Using waters low in nutrient content a "dilution" of the P-content in the lake may be achieved. In Lake Mueggelsee, Berlin, River Spree flows during the late summer through the lake, thereby flushing out the nutrients redissolved from sediments. In the cold season the Mueggelsee-passage of the now nutrient-rich Spree can be avoided using a bypass around the lake via the Dahme waterway. The flushing sometimes improves the water quality even if total phosphorus in the flushing water is high (e.g. during high floods) due to the low utilizability of the $\mathrm{P}$ compounds from erosion for algae growth. Also the settling of these particles and capping the sediments with silt may improve the water quality as could be demonstrated on small lakes (own investigations at Breitunger Seen, unpublished).

In addition, in deep water bodies during thermal stratification the highest nutrient concentrations which are found in the deepest waters, can be reduced by using the bottom outlet to drain away this nutrient-rich water (Fig. 2). 


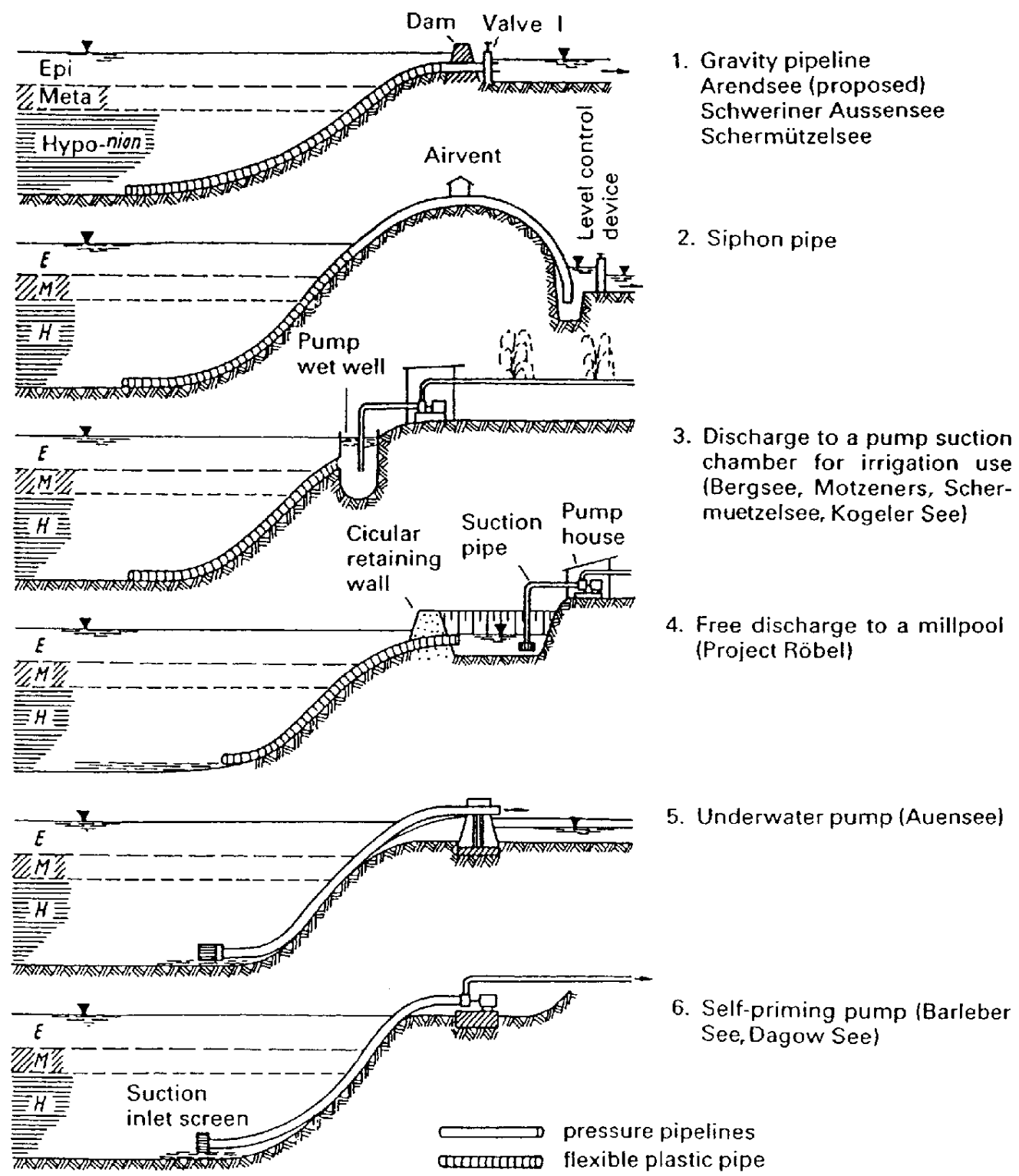

Fig. 3. Deep level abstraction; technological variants and typical cases in the former GDR (from Klapper 1991).

In natural lakes the export of nutrients from deepest layers may be realized by means of the so-called Olszewski-tubes. The first deep-level abstraction was attempted at Lake Kortowo in Poland, resulting in a significant oligotrophication (Olszewski 1961; Olszewski \& Sikorowa 1973). In Swizerland, Austria, Germany, and USA etc. many deep level abstractions have been installed. A measurable improvement in water quality will only be achieved in lakes with high flow through or with a RT of $2-5$ years (Schauser et al. 2002). In the former German Democratic Republic some of these facilities for deep water abstraction were built by agricultural companies. The use of irrigation waters was licensed only for nutrient-rich hypolimnetic waters, ex- tracted with flexible spiral wound plastic pipes (Klapper 1991). The technology was endangered, however, by high contents of $\mathrm{H}_{2} \mathrm{~S}$ in relatively small hypolimnia and stinking irrigation water (Fig. 3).

New concepts now being implemented combining the deep water delivery with an on-site external $\mathrm{P}$ elimination. The treated water is fed back into the lake by pipe to the depth of the adequate temperature somewhat above the level of the intake. The so-called PELICONtechnology is a combination of precipitation, flocculation and flotation with compressed air. The continuous intake of $\mathrm{P}$ and its redissolution from the sediments not only improves water quality but also the P-binding capacity of the sediments (Keil 1995; Fitschen 2002). 


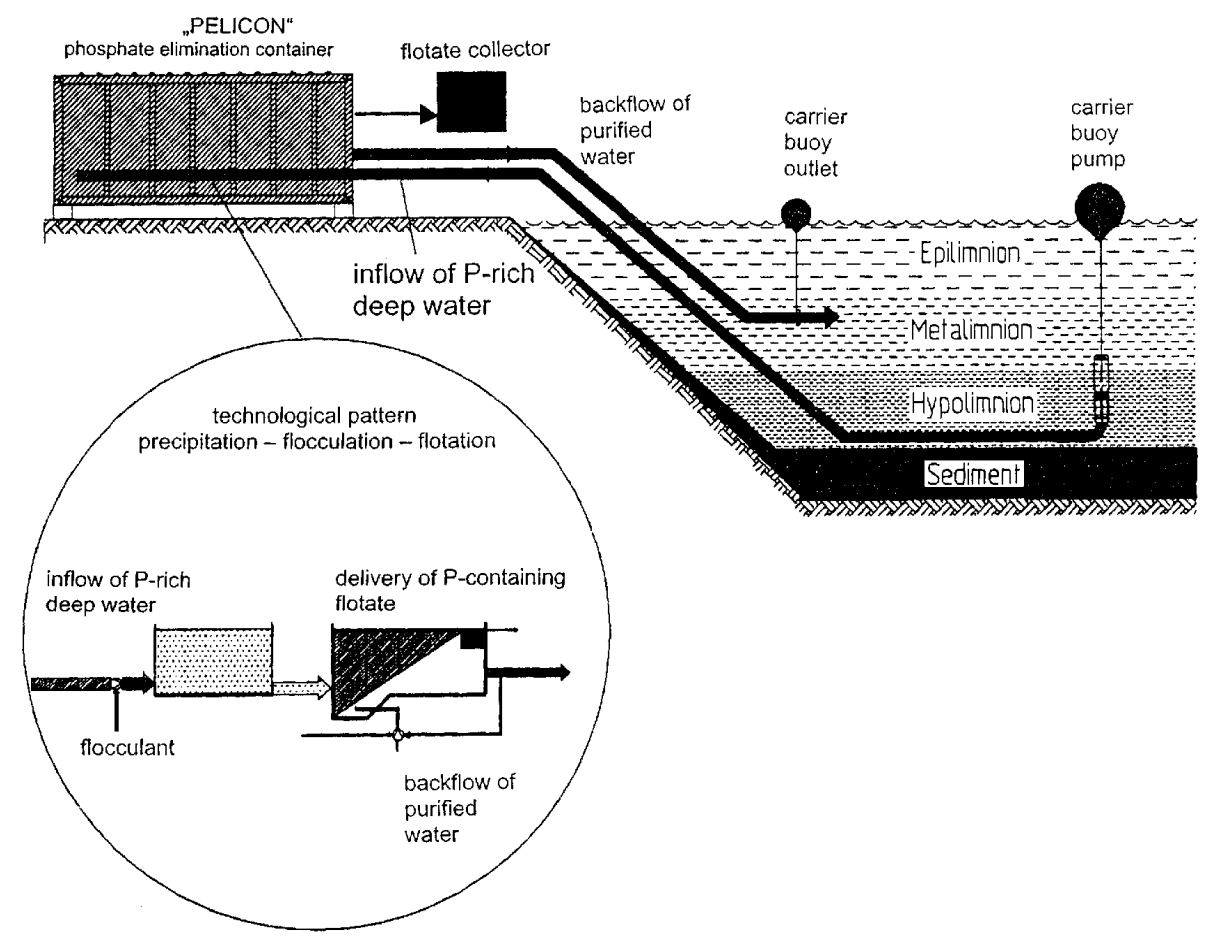

Fig. 4. Transportable on-site phosphorus elimination plant "PELICON" (sensu Keil 1995).

In June 2001 such a P-elimination plant was installed at the Kleiner Seddiner See with inlet TP concentrations of 80 to $100 \mu \mathrm{gl}^{-1}$ and a backflow (target) of $<20 \mu \mathrm{gl}^{-1} \mathrm{TP}$. The treatment costs in the first year where $43 € \mathrm{~m}^{-3}$ (Vietinghoff 2001, 2002) (Fig. 4).

Other P-elimination technologies use harvesting of phytoplankton: Algae-rich waters are skimmed with a special shovel from the surface of eutrophic waters and the algae with the nutrients incorporated are diverted mechanically by filters. An other option is a second filter step with P-adsorbing granules (Stelling 2002).

For small lakes Richert (2002) designed a floating phosphorus elimination plant "NESSIE" on the basis of a filter with porous adsorbing granules with a large specific surface area of $300 \mathrm{~m}^{2} \mathrm{~g}^{-1}$. Lake water is pumped over the filter using a wind-solar hybrid system as the energy source $(150 \mathrm{Wh})$. The P-loading capacity under laboratory conditions is about $60 \mathrm{~g} \mathrm{~kg}^{-1}$ adsorbent, but may be half as much in situ. The loaded adsorbent is suitable to be used as fertilizer.

Under the climatic conditions prevailing in the Ukraine, it is possible to harvest the floating algae layers during "water blooms" and thicken it by flowthrough separators and diverse drying steps. Sirenko \& Gavrilenko (1978) attempted to produce valuable biochemical matter from the skimmed algae and its largescale harvesting to counteract eutrophication.

In deep lakes a higher nutrient elimination during the stagnation period can be achieved using artificial mixing or destratification, so that deep waters with high nutrient contents are mixed with the epilimnetic waters, and exported with the outflow at the surface. In both, in deep and shallow lakes long-term scale the destratification increases the nutrient export, but short term effects differ. The most often applied method for destratification is the introduction of compressed air by boreholes in pipes inserted in horizontal position above the lake bottom. The air-water mixture with lowered specific weight causes a rising water curtain, destroying stratification and ideally the lake remains fully circulated the entire year. Other mixing technologies include pumping oxygen-oversaturated water from the surface down to the highest deficit near the sediment (MIXOX). The $\mathrm{O}_{2}$ deficient water may be transported from the depth to the surface using rising pipes (aerohydraulic guns) or modified deep water aerators. The oxygenation of the deeper water takes place partly by the air-lifting, but mainly at the large surface of the lake. Further, under some specific local circumstances, where in a series of reservoirs or lakes, an oxygen-saturated lake is followed by a lake that is stratified and has an anoxic hypolimnion, the flowthrough pattern can be changed: the inlet to the stratified lake is dammed $0.5 \ldots 1.0 \mathrm{~m}$ by a weir and from this storage the inflowing waters are led with help of a pipe to the greatest depth of the hypolimnion. This very cheap "ecotechnology" combines oxygen import into the anoxic hypolimnion and mixing due to the higher temperature (Fig. 5 and Tab. 3). 

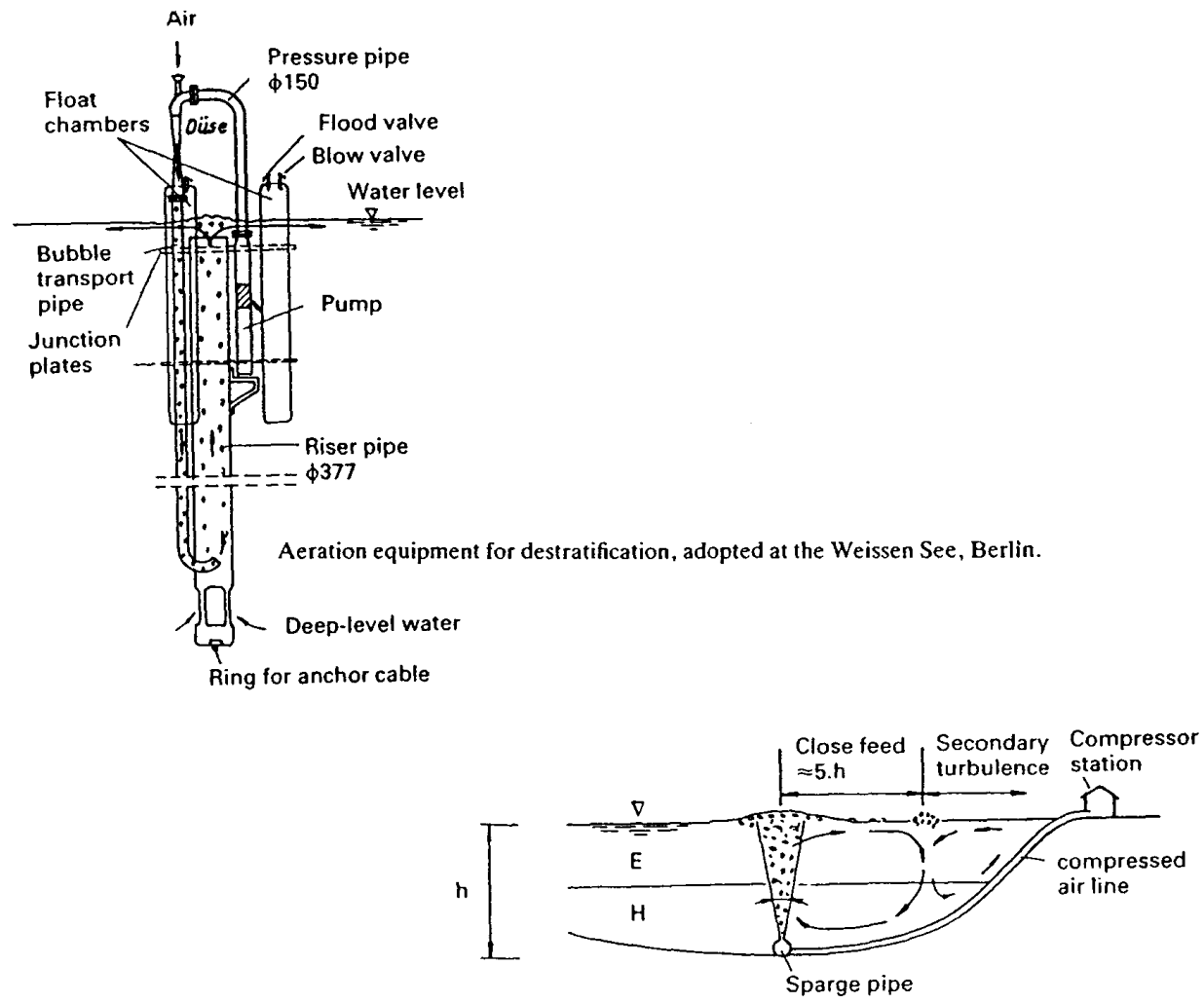

Destratification by means of linear input of compressed air.
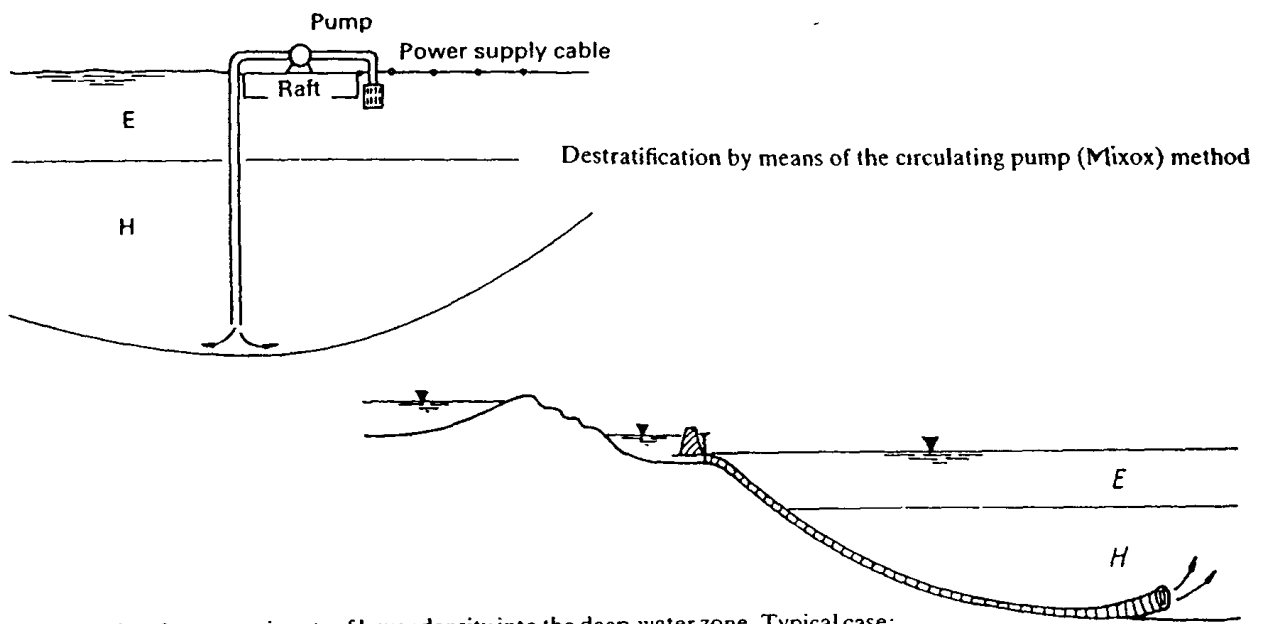

Entry of surface water inputs of lower density into the deep-water zone. Typical case: Jabeler See. (From Paul and Klapper 1985.)

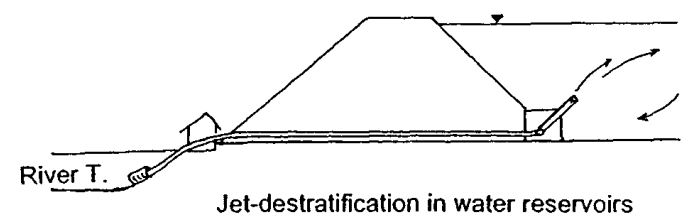

Fig. 5. Destratification technologies. 
Tab. 3. Increasing the nutrient export from a lake.

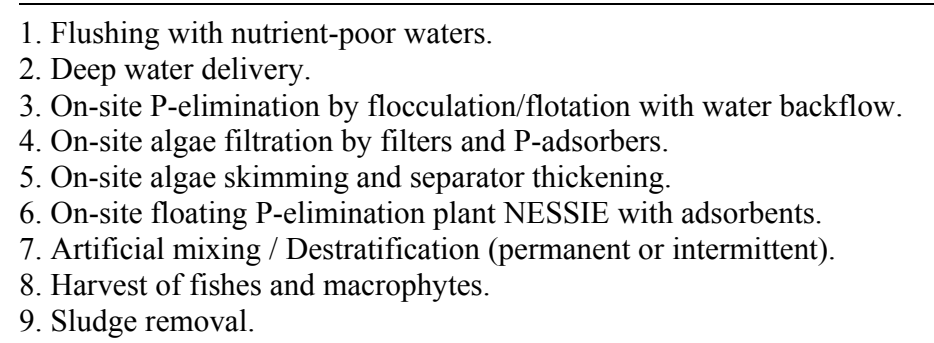

Fish harvesting influences the $\mathrm{P}$ budget only sporadically. Stocking of the lakes with fish sometimes introduces higher amounts of nutrients into the lake than the fishermen remove by their catches. But fishery may enhance the eutrophication by introduced certain fish and fish fodder. Bottom feeders like the carp intensify the redissolution of $\mathrm{P}$ from the sediments, the process is called as ichthyo-eutrophication (Rjabyshew 1972).

In shallow waterbodies dominated by macrophytes, removal and composting of the plants outsides may remove the biggest part of the TP. Harvesting should left over moderate stands of plants so as not to exchange macrophytes with phytoplankton, especially if the macrophytes are controlled using grass carps (Ctenopharyngodon idella). The lake can than become a weedfree but plankton dominated, and very turbid lake. A better option is the mechanical harvesting of the submerged plants at only the bathing places thereby keeping the water of the main ecosystem clean.

Removal of sediments is an expensive method for removing the $\mathrm{P}$, but it is the only possibility to counter rapid ageing and silting. After the sediment removal or de-sludgeing the lake is deeper, the volume and RT are higher and the oxygen demand and internal nutrient load are lower. De-sludgeing may be payable if there is a demand of organic matter for soil improvement in the lake surroundings. Few centimeter thick sludge layers, influenced by industrial (phenolic and cyanidic) wastes could be neglected due to dilution, where some meters of sediments were excavated to be used as soil additives in fruit plantages at Werder near Potsdam at the Havel lakes. The utilization of the lake sediments is an excellent example of a holistic landscape ecology: The organic matter and other fine particles such as the calcite crystals and plant nutrients originating from the sandy agricultural areas in the drainage basin and accumulated in the lake sediment, are brought back to the fields where they improve the fertility and especially the sorption capacity so that the nutrient losses from that areas will decrease in future. Some examples of the different technological measures for sludge removal are given in figure 6 .

However sludge removal may be very expensive if the agricultural utilization is impossible due to hazardous pollutants in urban and industrial regions (mercury, pesticide metabolics, heavy metals...). In such cases the separation of the mostly non-polluted sand and mechanical drying and the very expensive special deposition of the contaminated fine-grained materials is necessary.

\subsection{Increasing the P-sedimentation and preventing its re-dissolution}

Phosphorus precipitation with iron or alumn salts is the most common method to decrease the phosphate contents in the free-water of lakes with long RT:

$$
\begin{gathered}
\mathrm{M}^{3+}+3 \mathrm{H}_{2} \mathrm{O}=\mathrm{M}(\mathrm{OH})_{3}+3 \mathrm{H}^{+} \\
\mathrm{M}^{3+}+\mathrm{PO}_{4}{ }^{3+}=\mathrm{MPO}_{4}
\end{gathered}
$$

The formation of hydroxides predominates in the competitive processes. The metalphosphate is either occluded within the flocs or deposited on the outside. During the formation of the hydroxide flocs, considerable quantities of $\mathrm{H}^{+}$ions are released, which reduce the carbonate hardness, thereby reducing the buffering capacity:

$$
\mathrm{HCO}_{3}{ }^{-}+\mathrm{H}^{+}=\mathrm{H}_{2} \mathrm{O}+\mathrm{CO}_{2}
$$

In very soft waters with carbonate hardness below $10 \mathrm{mg} \mathrm{l}^{-1} \mathrm{CaO}$, the addition of only $3 \mathrm{mg} \mathrm{l}^{-1} \mathrm{Al}^{3+}$ leads to a complete loss of the buffering capacity and further $\mathrm{Al}$ dosage would result in an ecologically unacceptable $\mathrm{pH}$ decrease. For P-precipitation in soft water lakes, the combination with neutralizing components like lime is useful (Panning, pers. comm.).

For applying iron salts as flocculants, the redissolution of the phosphates under anoxic conditions has to be considered. Therefore, the technology should include a sediment oxidation with nitrate and additional liming against acidification (Ripl 1978). A very long lasting Pflocculation with liquid aluminium sulphate was performed in 1986 at Barleber See near Magdeburg (Roenicke et al. 1995). The waterblooms with cyanobacteria have not returned in the 17 years thereafter and macrophytes again made the clear water stage to persist. The remarkable long-term effect was caused by the sediment capping with aluminium hydroxide/ aluminium posphate. Before the Al-flocculation each oxygen depletion in the small hypolimnion was followed by Predissolution. Until today the binding capacity of this layer holds back the $\mathrm{P}$ in the sediment even under anoxic conditions (Roenicke et al. 1995).

This explains why aluminium compounds are preferred to those of iron. Also easier handling of the less aggressive chemicals during the application contributes 

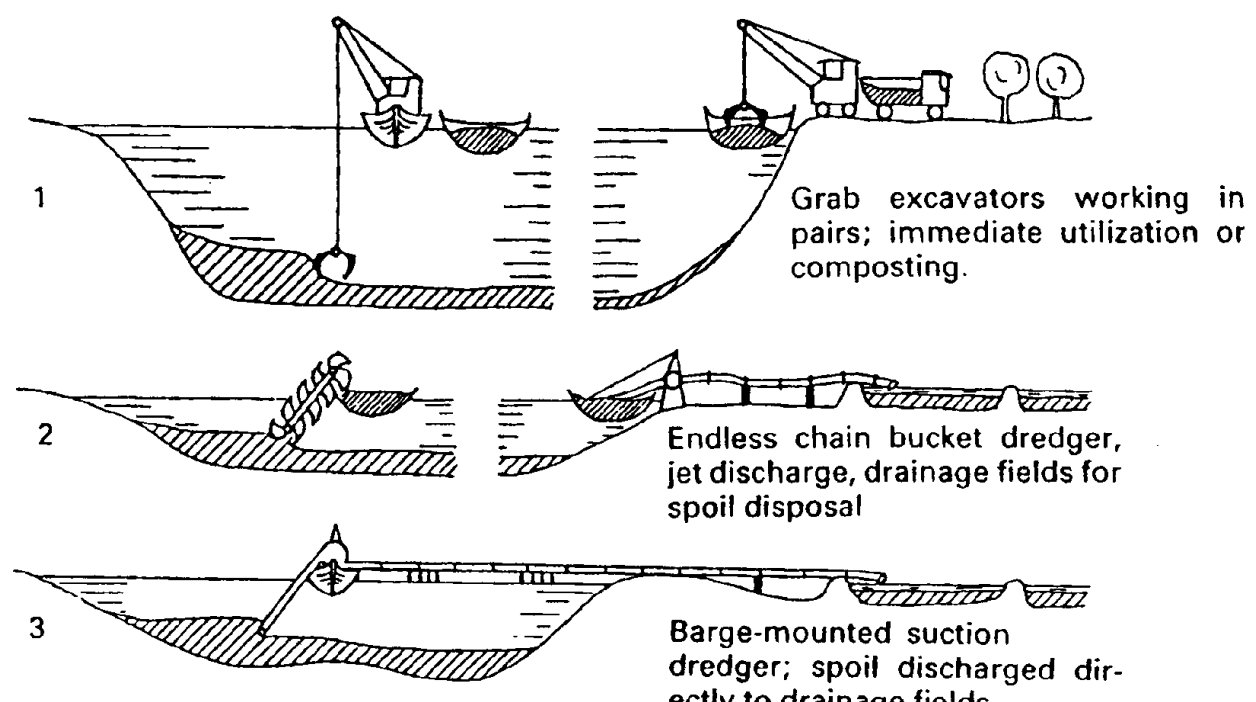
dredger; spoil discharged directly to drainage fields
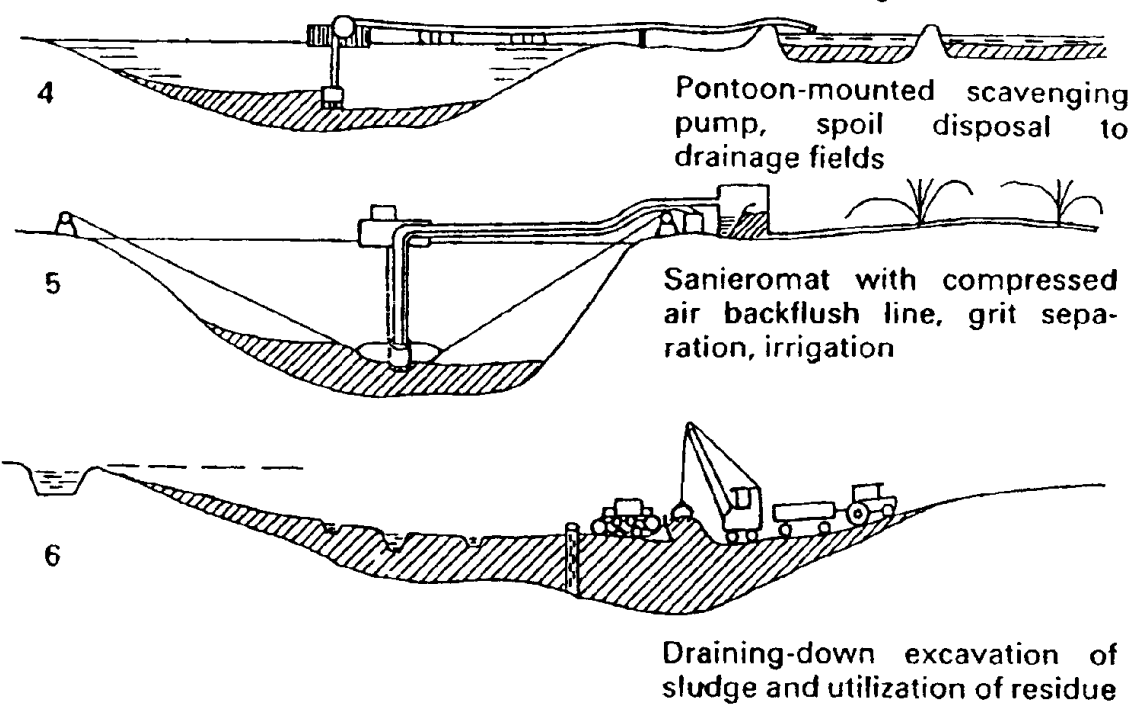

Large-scale measures for desludging of static bodies of water. Typical examples 1. Netzener See, Rangsdorfer See; 2. Neuendorfer See; 3. Beverinsee; 4. Kattensteeg See; 5 . Leipesee; 6 . Haselbach interception basin,Large pond at Torgau.

Fig. 6. Large-scale measures for sludge removal from lakes or reservoirs (after Klapper 1991).

to the preference for Al. Today many different flocculants, as well as many flocculant aids like polyacrylamide, bentonite, clay powder etc. are available and for each case the dosage may be optimized (Tab. 4) Technological realizations are given in figure 7.

Calcite may serve as an active barrier material and as sediment capping. The result of the P-binding of different technical products depend on particle size, specific surface-area and on the fine structure of the calcite applied. Experiments show, that the stability of the calcite barrier was destroyed by bioturbation of benthic organisms within 4 month (Donnert et al. 2002; Berg et al. 2002). The coccolithic lime, formed several million years ago belongs to those with extremely large specific surface area and good sorption ability. A combined restoration approach with polyaluminium chloride and coccolithic lime was successful at Auensee in Leipzig, and 2002 the long-lasting dominance of the Microcystis was broken (Menschel, pers. comm.).

The idea to utilize natural littoral calcite layers for sediment capping resulted in relatively modest P-reductions in the free water. $57,000 \mathrm{~m}^{3}$ internal lake lime were flushed 1996 with help of a cutter-head suction dredger and spread on the bottom of the $5 \mathrm{~km}^{2}$ big lake 
Tab. 4. Increasing the phosphorus flux to the sediment and curbing the re-dissolution.

1. Phosphorus precipitation with iron salts $\left(\mathrm{FeCl}_{2}, \mathrm{FeCl}_{3}, \mathrm{FeSO}_{4} \ldots\right)$ alone and combined with nitrate and $\mathrm{Ca}(\mathrm{OH})_{2}$.

2. Phosphorus precipitation with aluminium salts $\left(\mathrm{AlCl}_{3}, \mathrm{Al}_{2}\left(\mathrm{SO}_{4}\right)_{3}, \mathrm{Al}(\mathrm{OH})_{2} \mathrm{Cl}, \mathrm{AlSO}{ }_{4} \mathrm{Cl}\right.$, Polyaluminiumchloride ...) alone and in combination with calcium carbonate.

3. Phosphorus precipitation with lime.

3.1. Direct application of calcium carbonate or calcium oxide/hydroxide $\left(\mathrm{CaO}, \mathrm{Ca}(\mathrm{OH})_{2}, \mathrm{CaCO}_{3}\right.$, coccolithic lime $)$.

3.2. Flushing of natural calcite layers (Arendsee).

3.3. Stimulation of calcite forming with addition of $\mathrm{CaO}$ and oxigen in the hypolimnion (Schmaler Lucin)

4. Sediment conditioning with oxidizing chemicals or aeration.

5. Sediment capping with sand (Hamilton harbour).

6. Sediment capping with clay from gravel excavation or clay powder (pilot experiments).

7. Collecting the youngest sediments in "sediment traps".

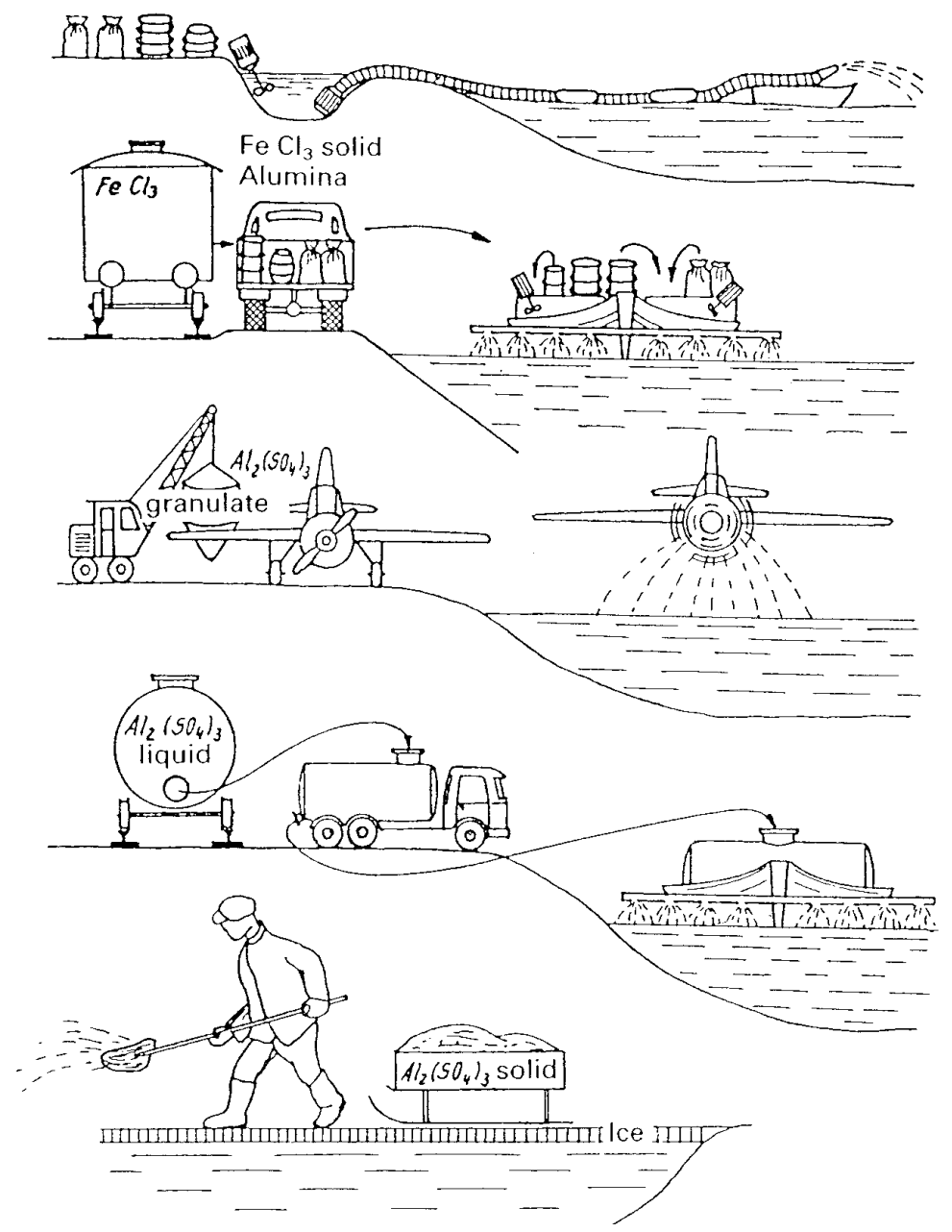

Fig. 7. Large-scale measures for phosphate flocculation in natural water bodies - case studies.

Arendsee, RT 114 years (Hupfer et al. 1996). Nevertheless, the cyanobacteria, especially nitrogen binding species, decreased and the Secchi-depth increased. It seems, that a stimulation of the diatoms has changed the interrelations within the algae community in a more suitable direction and contributed to control unwanted bloom-forming cyanobacteria (Roenicke 2002).

A pilot plant for restoration of the deep lake Schmaler Luzin $\left(Z_{\max } 34 \mathrm{~m}, Z_{\text {mean }} 14.7 \mathrm{~m}\right.$ and RT $\left.4.4 \mathrm{a}\right)$ is in operation since 1996. It consists of a deepwater aerator and a shore station for the addition of $\mathrm{Ca}(\mathrm{OH})_{2}$ into the aerated water. Keeping the hypolimnion oxic during the whole stagnation period and enhancing of calcite precipitation by oversaturation, have led to decreased SRP-content, at first in the hypolimnion but later in the whole lake (Koschel et al. 1998). A similar facility operates in Alberta, Canada (Prepas et al. 1997). The P-binding of the sediments can be increased using a chemical oxidation with calcium nitrate (LIMNOX) or nitrate embedded in a matrix of iron hydroxide (the socalled DEPOX-Fe). Up to $80 \%$ of the ironhydroxidematrix may be replaced by aluminium hydroxide 
(DEPOX Al/Fe). Contrary to the hypolimnion aeration or to the destratification, nitrate solution, due to the density of about 1.5 , tends to penetrate into the surface layer of the sediments. The iron/aluminium-matrix prolongs the availability of the very easy soluble nitrates for more than a year. The P-binding capacity amounts to $18 \mathrm{~g} \mathrm{PO}_{4}$-P per kg dry matter (Hillbrecht, pers. comm.).

Sediment capping is another way for preventing Predissolution. In this respect, sand and clay minerals are currently being investigated (Zeman et al. 1997; Quandt 2001). An interesting question relates to the behaviour of benthic organisms: while chironomids are impaired by a $2 \mathrm{~cm}$ clay cover, the tubificids immediately bioturbate the uppermost layer, which is then recovered by black particles from below the clay layer. Big mussels are not impaired but the Dreissena fixed to the substrate cannot survive under a clay cover. Sediment capping with clay occurs as a side-effect during the underwater sand and gravel excavation. During the wet excavation the mining lakes become turbid from the clay resuspension. But, after the mining has terminated the fine particles settle and clear and P-poor water allows macrophytes to grow. Measures for supporting macrophytes such as lowered water table, controlling plant-feeding animals or introducing suitable macrophytes belong to restoration tools aimed at preventing algae-dominated turbid waters. Fresh sedimented plankton organisms with their high contents in organic matter, $\mathrm{P}$ and microbes contribute importantly to nutrient redissolution, and therefore need to be moved to excavated traps and collected by "funnel effect".

\subsection{Food-web manipulation}

In addition to the diverse hydromechanical and chemical technologies many biological methods of eutrophication control are now available. These include changing the fish stock to a decrease in planktivores and a higher share of predator species. Thus the effect of prey fish on the zooplankton is reduced and the phytoplankton growth may be controlled by the filter feeders. The best solutions should combine reductions of nutrient loadings, repeated reductions of planktivorous and benthivorous fish stocks, and concurrent establishment of piscivorous stocks. Available evident suggests, that removing of fish populations could provide the trigger needed for complete lake recovery. Lake recovery has been achieved this way especially in Denmark, in the Netherlands, Norway, Sweden, Great Britain and Germany (Benndorf 1980, 1987; van Donk et al. 1989; Meijer et al. 1989; Harper 1992; Gulati \& van Donk 2002). Biomanipulation studies stimulated limnological research on the interrelations in food webs in lakes. Some unexpected developments were caused by water fowl, snails, mussels, carnivorous zooplankton, filamentous algae, changing species of water plants, weather etc. Many questions have to be answered by limnologists also in future. On all constellations how- ever, biomanipulation is more effective if nutrient loads are reduced (Moss 1999). On high trophic level at Bautzen Reservoir a failure happened in some years when colony-forming bluegreens that cannot be grazed by the zooplankton were indirectly stimulated and thus dominated the phytoplankton community (Benndorf 1990). In Lake Eymir (Turkey) poor water clarity persisted, also after 1995 effluent diversion has reduced the areal loading of TP and dissolved nitrogen (DIN) to $88 \%$ and $95 \%$. Domination of the fish stock by planktivorous tench (Tinca tinca) and the benthivorous carp (Cyprinus carpio) appeared to perpetuate the poor water conditions. A substantial fish removal effort over one year achieved a $57 \%$ reduction in the fish stock which led to a 2.5-fold increase in transparency. A strong topdown effect of fish on the large sized grazers was evident as density and the body size of Daphnia pulex increased significantly after the fish removal. A weak reestablishment of submerged plants might be attributed to inappropriate chemical conditions of the oxygen deficiency of sediments and high coot (Fulica atra) density (Beklioglu et al. 2003). Blumenshine et al. (2003) compared the potential predation pressure on Lake Kinneret herbivorous zooplankton by bleak (Acanthobrama terraesanctae) and the other major zooplankton predators in the lake, the cyclopoid copepods Mesocyclops ogunnus and Thermocyclops dybowskii. Despite having much lower biomass, the copepods accounted for a greater portion of the predation mortality on herbivorous zooplankton than bleak. Thus reductions in bleak predation pressure may allow for increases in cyclopoid copepod abundance and thereby a net increase in predation pressure on herbivorous zooplankton.

Macrophytes are combattants for phytoplankton in the use of the limited nutrients and they provide niches for zooplankton and periphyton. To allow a better macrophyte growth, the water table may be lowered that light may penetrate to the bottom. They may be planted by hand as starting cultures to develop the wanted bank and outlet "bioplateaus" and as floating reed or raft bioplateaus (simultaneously suppressing floating algae blooms). On the other hand, too many macrophytes may be nuisance for other lake uses by humans. That is true especially with so-called neophytes and neozoons, introduced from foreign countries. Without their natural enemies such plants like Eichhornia crassipes, Salvinia natans, Elodea canadensis, Myriopyllum spicatum and others tended in their new environment to mass developments causing huge economic damages. The search of insects for biological control was successful in the countries of their origin and with mining beetles or other insects the mass growth could be stopped (Cooke et al. 1993). Health impacts caused by Bilharziosis from the parasitic trematodes Bilharzia haematobium were reasons to search the natural enemies which could be introduced to one or the other link of the chain of life of the worm with its complicated host change. Snails 
(Pomatia sp.)were found, feeding the eggs of the host snail Biomphalaria glabrata (Paulini, pers. comm.). The macrophytes as habitats of the snails may be controlled etc.. In Europe a less dangerous helminthosis causes the bathing dermatitis by the trematod Trichobilharzia szidati. The main way for control is the decrease of the hosting snails with feeding fishes like Tinca tinca, the control of aquatic weed (or application of copper sulphate). Plant feeding fishes are used for biological plant control. In Germany, however, the exotic fishes (Ctenopharyngodon idella, Hypophthalmichthys molithrix and Aristichthys nobilis) are no longer allowed to introduce. The danger of an uncontrolled reproduction is small though, in view of the low temperature in springtime. The many different technologies for a water quality management by food-web manipulation need a high standard of symptom diagnosis and ecosystem knowledge for appropriate decision-making.

\section{CONTROL OF ORGANIC LOAD (SAPROBIZATION)}

In the industrialized countries the sewage load is reduced with help of rational water uses and sewage treatment. Also the biological purified sewage contains nutrients and increases oxygen demand at least indirectly by eutrophication and degrading biomass. Therefore, for most German lakes "zero load" is the objective. The biggest reservoir in the former GDR, the Bleiloch Reservoir on the upper Saale river with 200 million $\mathrm{m}^{3}$ was heavily loaded with paper pulp waste that led to total anoxia of the reservoir water and the emission of $\mathrm{H}_{2} \mathrm{~S}$. The sewage treatment plant could not reduce the huge oxygen demand. The post treatment was performed in the reservoir with 14 large deepwater aerators and for accidental loading peaks additional chemical oxygen was supplied by injecting several thousand tons nitrate per year into the treated sewage before it entered the reservoir. The continuation of the cellulose production after German unification was licensed only with reconstruction of an adequate treatment facility (Klapper 1991).

A new remediation method which directly affects lakes is the re-wetting of former bogs and wetlands. If carried out too quickly (one or a few years), the outflow of the re-wetted areas will be rich with humic matter and contain high concentrations of total carbon and phosphorus due to the degrading terrestrial vegetation. These substances inevitably create a high oxygen demand in the lake which can lead to fish kills as observed in the case of the Rambower fen and downstream situated Rudower See (Meissner et al. 2001).

Problems with high organic loading of lakes and reservoirs are common in many developing countries, especially around the megacities with often insufficient sewage treatment facilities. Where the water bodies and their self-purification potential are used, rather than treatment plants, the first discernible effect is oxygen depletion, and consequently fishkills occur. Some tropical reservoirs exhibit high $\mathrm{H}_{2} \mathrm{~S}$ production and the water at bottom outlet has to be aerated to protect fish-life in the river downstream (Klapper 1997). Most reservoirs, built for hydropower generation, can be artificially aerated, by adding oxygen via surface aerators, via destratification facilities or by hypolimnion aerators. The aeration of the activated sludge in sewage treatment plants would have been the more economic method for satisfying the oxygen demand. In the Funil Reservoir (Rio de Janeiro) the consequences of a lowered water table could be demonstrated. During the dry season the level was lowered by $15 \mathrm{~m}$, thereby the RT is shortened from 30 days at full storage to 14 days with lowered water table. That is true only for the relation between volume and the annual mean of the inflow. In reality the RT is higher in the dry season, due to the now decreased flowthrough. The runoff from thunderstorm rainfalls, which is sediment-laden from erosion, passes through the reservoir mostly as an underflow near the bottom due to its high specific weight. Nearly all morphometric factors influencing the water quality, such as volume, area, maximum and mean depth, area of drainage basin related to area and volume of the lake are less suited during low water situation. Using Ryding and Rast's (1989) classification, the reservoir belongs to class 3 (eutrophic) during low water table instead of 2 (mesotrophic) during full storage. In addition to required decrease of the organic and nutrient load as well as the erosion from the arable land, an increase of the RT was recommended by introduction of backpumping during the night hours and artificial mixing to prevent short circuits and approaching the real to the theoretical RT.

The Billings Reservoir (Sao Paulo) has been loaded with untreated sewage for decades. To increase the hydropower generation it was useful to pump water from Tiete river into the reservoir because this way the difference in altitude to the atlantic could be utilized energetically. The big problem was, the Tiete was misused quasi as the main collector for the capital. Now the Billings Reservoir is needed to satisfy the growing drinking water demand. Since 1993 it is forbidden to introduce Tiete water into the reservoir. The problems with the water quality have decreased after a few RT but the sediments contain contaminants such as hydrocarbons, heavy metals etc. and their presence in drinking water is undesirable. In the special case of the huge Billings Reservoir there is the best approach for a restoration to wait some years for capping and isolation by naturally produced algae gyttja (Klapper 1997).

\section{CONTROL OF ACIDIFICATION IN LAKES}

The acidification by acid rain and by pyrite oxidation has to be controlled using special neutralizing technologies. Addition of alkaline compounds is useful only in soft waters acidified by increase of $\mathrm{SO}_{2}$ and $\mathrm{NO}_{\mathrm{x}}$ from burning processes and from traffic emissions, 

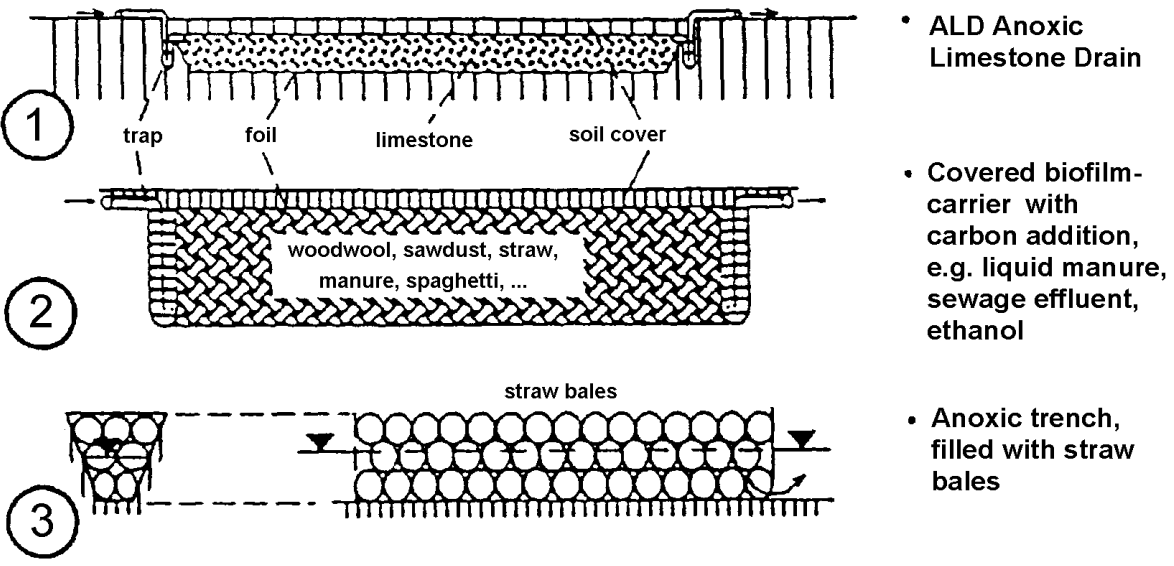

- Anoxic trench, filled with straw bales
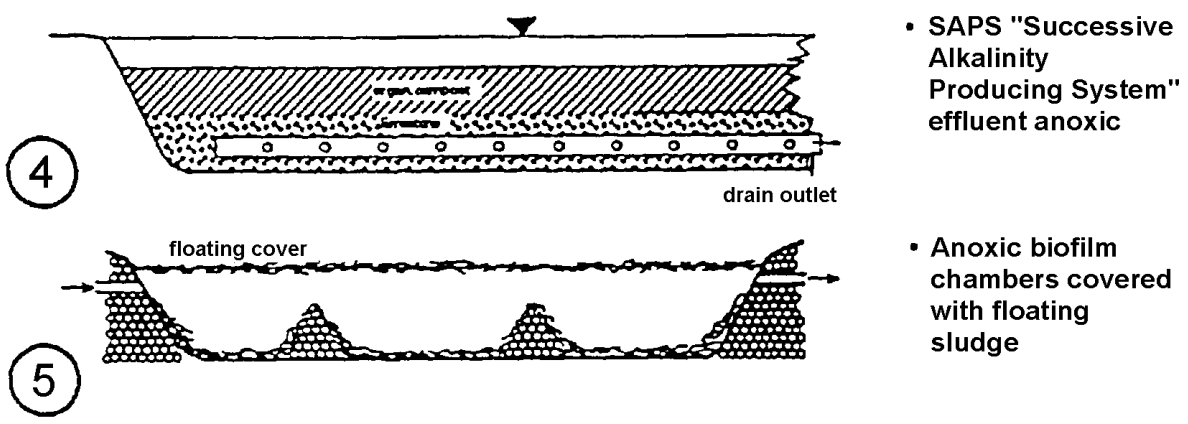

- Anoxic biofilm chambers covered with floating sludge

(6)

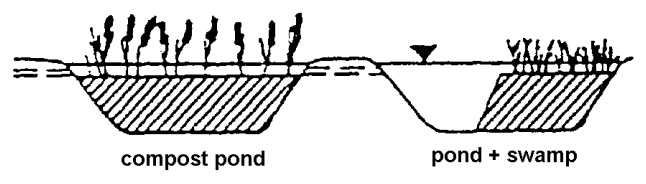

(7)

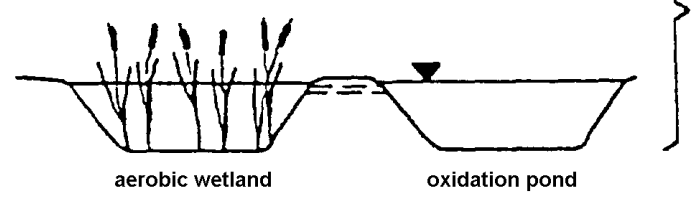

(8)

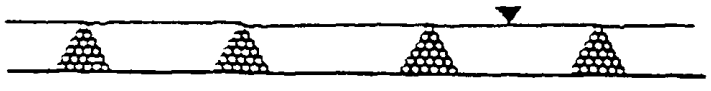

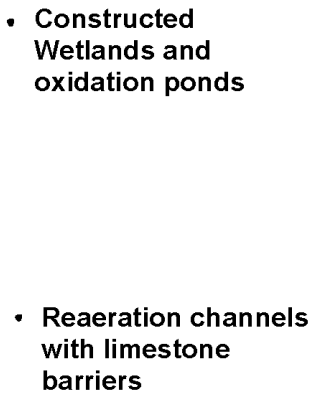

Fig. 8. "Service ecosystems" for neutralization of acidic effluents (from Klapper \& Schultze 1997).

which spread over long distances with the wind. The typical $\mathrm{pH}$ of rain acidified soft-water lakes is about 4.5 to 5.5, the scale of aluminium buffer. In thousands of cases the neutralization was achieved by adding $\mathrm{CaCO}_{3}$ powder with help of aircraft in Sweden, Norway, Canada and USA. The measures have led to the return of fish life and the neutralization measures are an example of success in lake restoration (summary in Olem 1991).

The geogenic acidification caused by pyrite-oxidation is far more complicated. The typical pH of geogenic acidified hard-water lakes is 2.0 to 3.5 buffered by high concentrations of iron. Here, the alkalinity demand for a chemical neutralization is one to three orders of magnitude higher than for neutralizing rain-acidified waters. Microbial reduction of the high sulphate- and iron contents leads finally to the formation of $\mathrm{FeS}_{2}$ the main cause of acidification. The conditions necessary for the sulphate reduction in a mining lake are contrary to those for eutrophication control. For sulphate reduction the environment has to be anoxic, carbon and phosphorus should be added to initiate the acidity-binding processes. Such conditions are found mainly in the sediments, but there are difficulties in including the liquids from the uppermost sediment layers in the water 


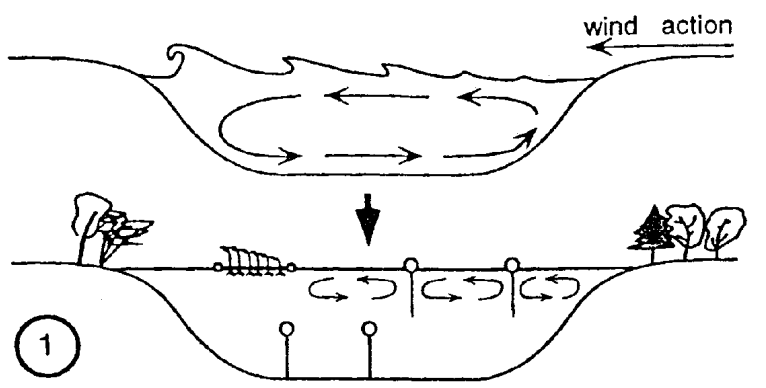

- Changing of polymictic mining lake into a stable stratified dimictic lake by swimming and submerged barriers, and by shore afforesta. tion

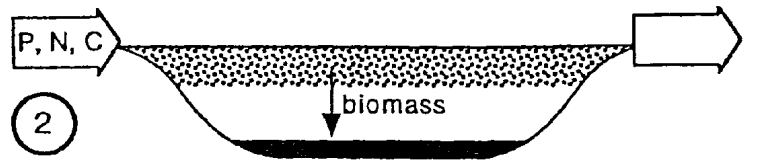

- Controlled surface water filling and throughflow: bicarbonate, nutrients and organic load stimulate alkalinisation of the free water and on sediments

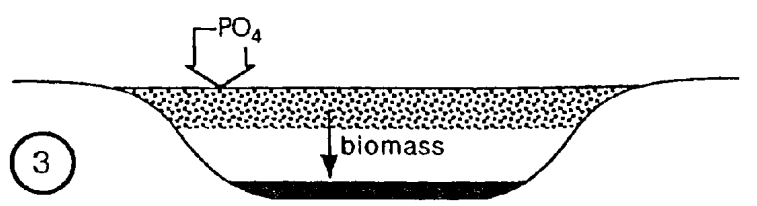
or

- Fertilization by phosphorus for controlled eut rophication

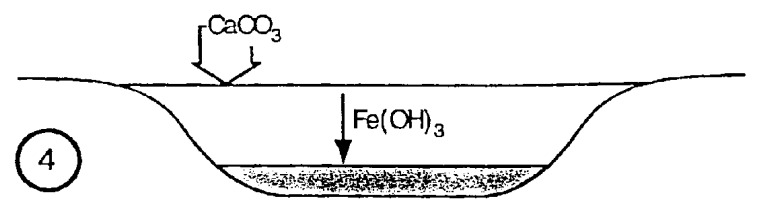

- Liming for iron flocculation or-utilisation of neutralized groundwater from a ground. water treatment plant

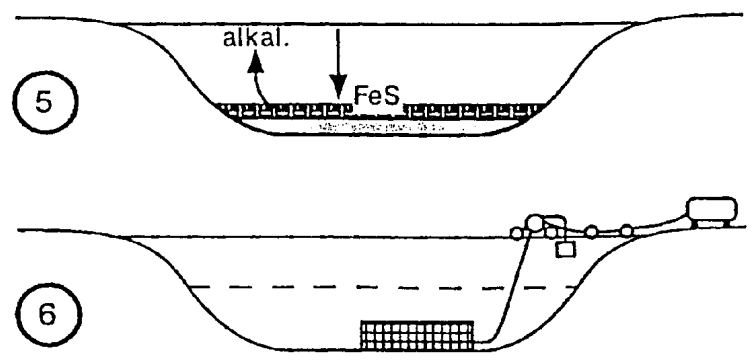

- Capping the sediments with degradable organic matter to support the sulfidic binding of heavy metals and acidity

-Installation of an upgrowth reactor and addition of a carbonsource sulfate reduction in the anaerobic hypolimnion

Fig. 9. Abatement of acidification by in situ-technologies (from Klapper and Schultze 1997).

circulation and the matter exchange. In large enclosures, filled with acidic water, straw bales and carbolime (byproduct of sugar production), the microbial process of desulphurization has just been attempted in the mining lake 111 in Lusatia, Germany. First results are promising (Frömmichen 2000; Koschorrek et al. 2002).

The abatement of geogenical acidification should be realized in all steps of the mining process: preparation, performance and recultivation of the landscape. Exposure of the pyrite containing minerals and other materials to the atmospheric oxygen has to be minimized. Layers with the highest pyrite levels should be buried in the deepest part of the mine. For filling the new forming lakes, surface water with high carbon hardness showed to buffer and neutralize the acidity. Several neutralizing technologies are known for acidic effluents from mining areas (Fig. 8). The neutralization of large acidic lakes is still an unaccomlished solved problem. Some approaches are shown in figure 9.

\section{SALINIZATION}

The salinization of inland waters has different reasons. Sometimes more water is extraced and used than available. Especially the irrigation of desert soils leads to losses by evaporation. Water shortage in L. Aral, in the Dead Sea, L. Tschad, L. Nasser and some lakes in the aridic part of the USA belong to the most severe environmental problems on a global scale. Changes in hydrologic regimes in the above mentioned areas have serious consequences for the water quality too. Water 
Tab. 5. Treatment of deposits and contaminations in and at mining lakes (from Klapper \& Geller 2001).

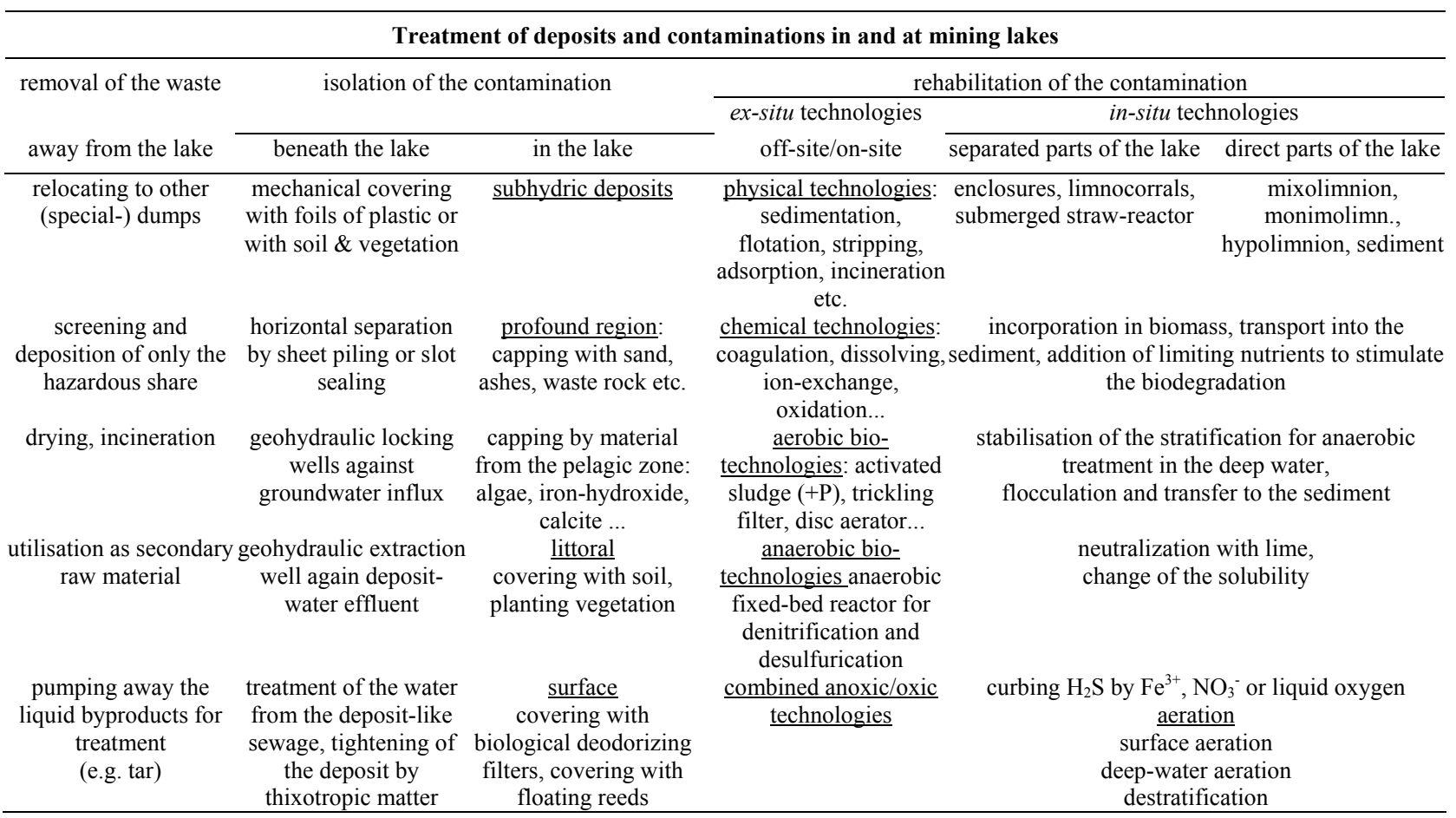

depth of Lake Sewan, Armenia, is reduced by $18 \mathrm{~m}$ due to very high extraction for hydropower generation. A $40 \%$ loss of the volume and $12 \%$ of the area has the same effect as eutrophication: hypolimnion oxygen deficit, diminished Secchi-disc visibility, and development of bluegreen blooms (Meschkova 1976).

The salt layers at the bottom of some (mining) lakes leads to increased stability of stratification, increase of oxygen deficit, and accumulation of hydrogen sulfide, methane and ammonium in the deepest part of the meromictic lakes. The monimolimnion represents an extremely long RT with all problems for restoration such waters. Destratification, the most widely used measure in lake restoration, is dangerous because of the byproducts of anaerobic degradation and their greater oxygen demand. Technologies such as oxygenation using nitrate or liquid oxygen are expensive alternatives.

\section{RESTORING A LAKE CONTAMINATED WITH HAZARDOUS SUBSTANCES}

Higher political priority given to development of industry and agriculture than environment protection in the $1960-1970$ s led to the pollution of lakes. Between 1927 and 1982, the north Italian Lake Orta was loaded by wastes from a rayon factory containing ammonium sulphate and heavy metals. Ammonium oxydation decreased the $\mathrm{pH}$ to between 3.8 and 4.4. An additional metal contamination $(\mathrm{Cu}, \mathrm{Cr}, \mathrm{Ni}, \mathrm{Zn}$ and $\mathrm{Al}$ ) caused serious impairment of the lake's ecosystem: most species of the phytoplankton, zooplankton and fish disappeared. About 18,000 tons of powdered limestone was added in 1989-1990 to restore the lake. This and termination of the industrial emissions led to a rise in $\mathrm{pH}$ to near neutrality in 5 years.

Ammonium decreased from 1.5 to $<0.1 \mathrm{mg}^{-1}$ (Calderoni et al. 1997). The restoration steps were accompanied by dilution with a high flowthrough. The studies are well documented (Bonacina 2001). This is the biggest liming campaign applied to date to a single lake (Geller 2002).

Opencast mining pits have been used by mining companies and the coal processing industry for dumping overburden, ash, coal dust, wastes from smoulderies and tar. Such deposits to the mining lakes of eastern Germany led to a great number of environmental impacts. The restoration of these impaired lakes require different rehabilitation approaches. Deposits and contaminations may be removed and treated or the contamination may be isolated on the shore or at the lake bottom. Technologies were developed for ex-situ or in-situ rehabilitation of the contamination (Tab. 5).

The following case study is a typical example of waste contamination from a lignite pyrolysis plant. For decades the effluents had been collected in a former open cast mine. Phenolic compounds were altered by oxidative polymerisation during storage into anthropogenic humic substances (AHS). The former mine had changed to a 9 ha large lake, maximum depth $27 \mathrm{~m}, 2$ million $\mathrm{m}^{3}$ volume and filled with a dark brown liquid with only $3 \mathrm{~cm}$ visibility and zero oxygen content. In the upper $10 \mathrm{~m}$ of the stratified water body the concentration of phenolic compounds amounted from 10 to 100 $\mathrm{mg} \mathrm{l}^{-1}$ and more than $200 \mathrm{mg} \mathrm{l}^{-1}$ in the deeper layers, where the chemical oxygen demand (COD) was as high 
as $2,290 \mathrm{mg} \mathrm{l}^{-1}$. The strong odour of organic sulphur compounds irritated the inhabitants of the region.

A traditional ex situ water treatment proved to be impractical. An unconventional in situ restoration strategy was tested in enclosures and used for full scale remediation (Stottmeister et al. 1999). The following steps were carried out:

1. flocculation of black A HS-macromolecules by ironIII-chloride solution ( $\left.3200 \mathrm{~m}^{3} 40 \%, \mathrm{pH} 4-5\right)$ resulting in a sedimentation of the flocs and discolouration of the water body;

2. neutralization of clear and uncoloured water body with $50 \%$ of the DOC before flocculation with 2.200 $\mathrm{m}^{3}$ limestone slurry of $20 \%$;

3. addition of phosphoric acid in increments (3 times $0.8 \mathrm{~m}^{3}, 75 \%$ ).

In only three years biodiversity in the upper aerobic zone increased similar to a natural lake. The studies have shown, that the higher the RT, the higher the stability of the system, and the more urgent is the need for applying restoration measures. But there is a great difficulty in determining the RT of such lakes with no surface inflow and outflow.

\section{CONCLUSIONS}

On a global scale, the factors causing water quality degradation and thus the restorative measures differ. Eutrophication, saprobization and microbial load, acidification, salinization and siltation, as well as contamination with hazardous substances are typical ecosystem stresses. The deviations from "natural" or "normal" conditions in the lakes demand adequate management measures based on monitoring results and decision support systems (Schauser et al. 2002). First, the RT has the effect of a buffer on the water volume. But the retention of the matter in the hypolimnion of the stratified lakes extends the dilution and remediation time, especially in meromictic lakes where the RT in the monimolimnion may be decades. The sediments with their accumulated matter have a similar delayed effect for rehabilitation. Therefore, the ecotechnologies for lake restoration begin with the control of flowthrough to bring the RT as close as possible to the theoretical value, the quotient of volume and flowthrough. At many (mining) lakes not yet connected to surface running waters, exchange with the groundwater is decisive of the RT. But it is not easy to distinguish groundwater inflow and outflow at different localities in such manmade lakes. Near the surface, the infiltration or exfiltration is highest due to the "filter cleaning" by wind and wave action. The deeper parts of the littoral are clogged by biofilms in the course of time. The bottom may be watertight where dead algae accumulate. A few metres further tailing piles may be free from sediments and groundwater enters without greater resistance. During the filling process the morphometric conditions are rapidly changing. Nevertheless, it is imperative to esti- mate RT as one of the main factors being deciding for success or failure of the restoration measures planned or performed.

\section{ACKNOWLEDGMENT}

The actual state of lake restoration therapy against eutrophication was presented in March 2002 during a workshop organized by the Institute of water Ecology and Inland Fishery Berlin (IGB). I would like to thank in particular the colleagues Jürgen Spieker and Burkhard Scharf who supported me with reference materials. Mrs. Hillbrecht kindly supplied data pertaining to new chemicals for P-binding and sediment oxidation. Dr. W. Geller, Section Head of the UFZ Institute for Water Research in Magdeburg provided information on geogenic acidification. Dr. Lindenschmidt and Dr. Gulati checked the English of the paper. I also thank the organizers for inviting me to participate in the Bolsena Conference.

\section{REFERENCES}

Allan, R.J. 1997. What is aquatic ecosystem restoration? Water Qual. Res. J. Canada, 32 (2): 229-234.

Beklioglu, M., O. Ince \& I. Tuzun. 2003. Restoration of the eutrophic Lake Eymir, Turkey, by biomanipulation after a major external nutrient control. Hydrobiologia, 490: 93-105.

Benndorf, J. 1980. Conditions for effective biomanipulation, conclusions derived from whole-lake experiments in Europe. Hydrobiologia, 200/201: 187-203.

Benndorf, J. 1987. Food web manipulation without nutrient control: a useful strategy in lake restoration? Schweiz. Zeitschrift für Hydrologie, 49: 237-248.

Benndorf, J. \& K. Pütz. 1987. Control of eutrophication of lakes and reservoirs by means of predams. I. Mode of operation and calculation of the nutrient elimination capacity. Wat. Res., 21: 829-838.

Benndorf, J. \& K. Pütz. 1987. Control of eutrophication of lakes and reservoirs by means of predams. II. Validation of the phosphate removal model and size optimization. Wat. Res., 21: 839-842.

Berg, U., T. Neumann, D. Stüben, U. Markert, K. Wurm \& D. Donnert. 2002. Einsatz von Calcit als Barrierematerial zur internen Seenrestaurierung. Teil 2. Praxisnahe Optimierung und Bewertung. IGB-Workshop Seentherapie, Blossin, Abstracts

Bernhardt, H. \& J. Clasen. 1985. Recent developments and perspectives of restoration for artificial basins used for water supply. Proceedings Intern. Congr. on Lake Pollution and Recovery, Rome: 213-227.

Blumenshine, S.C. \& K.D. Hambright. 2003. Top-down control in pelagic systems: a role for invertebrate predation. Hydrobiologia, 491: 347-356.

Bonacina, C. 2001. Lake Orta: the undermining of an ecosystem. J. Limnol., 60(1): 53-59.

Chorus, I. 1995. Müssen in der Seensanierung Gesamtphosphat-Schwellenwerte unterschritten werden, bevor das Plankton eine Reaktion zeigt? In: Jaeger, D. \& R. Koschel(Hrsg.), Verfahren zur Sanierung und Restaurierung stehender Gewässer. Limnologie Aktuell 8, Gustav Fischer Verl. Stuttgart: 21-28.

Cooke, G.D., E.B. Welch, S.A. Petersen \& P.R. Newroth. 1993. Restoration and management of lakes and reservoirs. $2^{\text {nd }}$ ed. Lewis Publishers Boca Raton, Ann Arbor, London, Tokyo: $558 \mathrm{pp}$. 
Donk, E. van, R.D. Gulati \& M.P. Grimm. 1989. Food web manipulation in Lake Zwemlust: positive and negative effects during the first two years. Hydrobiological Bulletin, 23: 19-34.

Donnert, D., P. Weidler, U. Berg, T. Neumann, M. Salecker \& U. Schweike. 2002. Einsatz von Calcit als Barrierematerial zur internen Seenrestaurierung, Teil I. Generelle Aspekte. IGB-Workshop Seentherapie, Blossin, Abstracts.

Fitschen, T. 2002. Pelicon-Anlage: Phosphat-Elimination zur Restaurierung geschichteter Gewässer. IGB-Workshop Seentherapie, Blossin, Abstracts.

Frömmichen, R. 2001. In-situ Sanierungsstrategie zur Förderung der mikrobiellen Entsäuerung von geogen schwefelsauren Bergbaurestseen - Mesokosmosstudien. Diss. Techn. Univ. Dresden: 155 S.

Gaedke, U. 1998. The response of the pelagic community of a large and deep lake (L. Constance) to reoligotrophication: Evidence for scale dependent hierarchical patterns. In: Bäuerle, E. \& Gaedke, U. (Hrsg.), Lake Constance, Characterisation of a ecosystem in transition. Archiv Hydrobiol, Adv. Limnol. 53: 317-333.

Geller, W. 2002. Acidification of fresh waters. In: Encyclopedia of Water, WILEY: (submitted).

Güde, H., H. Roßknecht \& G. Wagner. 2000. Prozesse der Reoligotrophierung - Fallbeispiel Bodensee. Münch. Beiträge Abwass.-, Fischerei, Flußbiol., 53: 323-346.

Gulati, R. D. \& E. van Donk. 2002. Lakes in the Netherlands, their origin, eutrophication and restoration: state-of-the-art review. Hydrobiologia, 478: 73-106.

Harper, D. 1992. Eutrophication of freshwaters. Principles problems and restoration. Chapman \& Hall, London, New York, Tokyo, Melbourne, Madras: 327 pp.

Hupfer, M. \& C.E.W. Steinberg. 1997. Auswirkungen von Restaurierungsmaßnahmen auf den Phosphat-Rückhalt in Sedimenten. Deutsche Gewässerkundl. Mitt., 41: 238-244.

Hupfer, M. \& B. Scharf. 2002. Seentherapie: Interne Maßnahmen zur Verminderung der Phosphorkonzentration. In: Handbuch Angewandte Limnologie, 14. Erg. Lfg.: 1-67.

Hupfer, M., R. Pöthig, R. Brüggemann \& W. Geller. 2000. Mechanical resuspension of autochthonous calcite (Seekreide) failed to control internal phosphorus cycle in an eutrophic lake. Wat. Res., 34: 859-867.

Imboden, D. \& R. Gächter. 1978. A dynamic lake model for trophic state prediction. J. Ecol. Modelling, 4: 77-98.

Keil, U. 1995. Phosphat-Elimination zur Restaurierung geschichteter Gewässer. Limnologie Aktuell 8. Gustav Fischer Stuttgart: 115-118.

Klapper, H. 1991. Control of eutrophication in inland waters. Ellis Horwood New York, London: 337 pp.

Klapper, H. 1998. Water quality problems in reservoirs of Rio de Janeiro, Minas Gerais and Sao Paulo. Internat. Rev. Hydrobiol., 83: Special Issue: 93-102.

Klapper, H. 2001. Mining lakes: generation, loading and water quality control. In: Mudroch, Stottmeister, Kennedy \& Klapper (Eds), Remediation of abandoned surface coal mining sites. Springer Berlin, Heidelberg, New York: 57-110.

Klapper, H. \& M. Schultze. 1997. Sulfur acidic mining lakes in Germany - ways of controlling geogenic acidification. Proceedings IVth Int. Conf. on Acid Rock Drainage, Vancouver. Vol. 4: 1727-1744.

Klapper, H. \& W. Geller. 2001. Water quality management of mining lakes - a new field of applied hydrobiology. Acta Hydrochim. Hydrobiol., 29(6/7): 363-374.

Koschel, R. 1997. Structure and function of pelagic calcite precipitation in lake ecosystems. Verh. int. Ver. Limnol., 26: 343-349.

Koschel, R., M. Dittrich, P. Casper \& T. Gonsiorcyk. 1998. Induzierte hypolimnische Calcitfällung zur Restaurierung geschichteter eutropher Seen. In: Entwicklung von Gewässertechnologien zur Sanierung von Talsperren und Seen. BMBF - Eigenverlag: 55-97.
Koschorreck, M., R. Frömmichen, P. Herzsprung, J. Tittel \& K. Wendt-Potthoff. 2002. Functions of straw for in situ remediation of acidic mining lakes. Water, Air and Soil Pollution: Focus 2/3: 97-109.

LAWA 1998. Gewässerbewertung - Stehende Gewässer Vorläufige Richtlinie zur Erstbewertung von natürlich entstandenen Seen nach trophischen Kriterien. Länderarbeitsgemeinschaft Wasser (Hrsg.) Kulturbuchverl. Berlin.

Meijer, M.L., A.J.P. Raat \& E.L. Mills. 1989. Restoration by biomanipulation of Lake Bleiswijke Zoom (The Netherlands): First results. Hydrobiological Bulletin, 23: 49-57.

Meissner, R., H. Rupp \& H. Klapper. 2001. Erfahrungen bei der Wiedervernässung von Niedermooren in Nordostdeutschland. KA - Wasserwirtschaft, Abwasser, Abfall., 48: $1127-1134$.

Meshkova, T.M. 1976. Gidrobiologiczeskij rezhim oz. Sevan posle iskustvennogo ponizhenija ego urovenja. Materials 3rd Congr. of the Hydrob. Society of the S.U. Acad.Sci. Riga, Vol. $2: 210-212$

Moss, B. 1999. British Phycological Society Presidential address 1999; from algal culture to ecosystem; from information to culture. Eur. J. Phycol., 34: 193-203.

Olem, H. 1991. Liming acidic surface waters. Lewis Publishers: $331 \mathrm{pp}$.

Olszewski, P. 1961. Versuch einer Ableitung des hypolimnischen Wassers an einem See. Ergebnisse des ersten Versuchsjahres. Proc. Int. Assoc. Limnol., 18: 1792-1797.

Olszewski, P. \& A. Sikorowa. 1973. Drawing off of hypolimnion waters as a method for improving the quality of lake waters. Symp. Eutrophierung und Gewässerschutz Reinhardsbrunn DDR, Abstracts: 136-141.

Paul, L. \& H. Klapper. 1985. Vorrichtung zur Destratifikation von Standgewässern. WPC 02/F 259 813-2

Prepas, E.E., T.P. Murphy, W.P. Dinsmore, J.M. Burke, P.A. Chambers \& S. Reedyk. 1997. Lake management based on lime application and hypolimnetic oxygenation: the experience in eutrophic hardwater lakes in Alberta. Water Qual. Res. J. Canada, 32(2): 273-293.

Quandt, T. 2001. Anwendung von Tonmineralien in der Seenbehandlung. Teil 2. Sedimentabdeckung. Wasser \& Boden, 53: 26-31.

Quandt, T., S. Sandrock \& E-M. Scharf. 2002. Phosphatfällung und Sedimentabdeckung mit Tonmineralien. $I G B-$ Workshop Seentherapie, Blossin, Abstracts.

Richert, O. 2002. NESSIE - schwimmende Entphosphatungsanlagen. IGB - Workshop Seentherapie, Blossin, Abstracts.

Ripl, W. 1978. Oxidation of sediments with nitrate - a restoration method for former recipients. Ed. Inst. of Limnology Univ. of Lund: $151 \mathrm{pp}$.

Rjabyshev, M. G. 1972. Gidrologiczeskaja charakteristika v. Moskvy, regulirovanie stoka $\mathrm{v}$ ee bassejne i vodochozjajstvennoe ispol'zovanie. In: Processy zagrjaznenija i samooczishcenija reki Moskvy. Strojisdat Moskva : 323.

Roenicke, H., M. Beyer \& J. Tittel. 1995. Möglichkeiten zur Steuerung der Blaualgendynamik in eutrophierten stehenden Gewässern durch Maßnahmen zur Seenestaurierung. In: Jäger, D. \& R. Koschel (Hrsg.), Verfahren zur Restaurierung stehender Gewässer. Limnologie Aktuell 8, Gustav Fischer Verl. Stuttgart: 133-156.

Roenicke, H., H. Klapper, J. Tittel, M. Beyer \& B. Zippel. 1997. Control of phosphorus and plankton by calcite flushing in Lake Arendsee: enclosure experiments. Verh. int. Ver. Limnol., 26: 768-771.

Roenicke, H., M. Beyer, B. Zippel, P. Herzsprung, W. Elsner \& G. Luther. 1998. Steuerung der Phosphordynamik und der Phytoplanktonabundanz durch Aufspülung seeinternen Kalzits. In: Entwicklung von Gewässertechnologien zur Sanierung von Talspern und Seen. BMBF - Eigenverlag: 99-131. 
Roenicke, H. 2002. Interne Restaurierungsmaßnahmen an zwei Badeseen in Sachsen-Anhalt zur Steuerung der PBelastung und der Cyanobakterien-Abundanz. IGB-Workshop Seentherapie, Blossin, Abstracts.

Ryding, S.-O. \& W. Rast (Eds). 1989. The control of eutrophication of lakes and reservoirs. MAB Series Vol. 1 UNESCO, Paris and The Parthenon Publishing Group, Carnforth: 314 pp.

Sas, H. et al. 1989. Lake restoration by reduction of nutrient loading. Expectations, experiences, extrapolations Academia Verl. Richarz GmbH, St. Augustin.

Scharf, B. W. 1995. Seentherapie. Habilitationsschrift Universität Braunschweig.

Schauser, I., J. Mathes, B. Scharf \& M. Hupfer. 2002. Entscheidungsfindung und Entscheidungshilfen bei der Seentherapie. Wasser \& Boden, 54(9): 14-20.

Sirenko, L.A. \& M.J. Gavrilenko. 1978. Water bloom and eutrophication. Naukova Dumka Kiev: 231 pp. (in Russian).

Sondergaard, M., J.P. Jensen \& E. Jeppesen. 2001. Retention and internal loading of phosphorus in shallow, eutrophic lakes. The Scientific World, 1: 427-442.

Stelling, A. 2002. ALGASAN-kombinierte Algen-, Trübstoffund Phosphatelimination. IGB-Workshop Seentherapie, Blossin, Abstracts.
Scheffer, W., S. Hother \& H.-W. Uhlmann 1999. Gewässerexterne Phosphatelimination am Süßen See. WLB Wasser, Luft und Boden, 3: 22-25.

Stottmeister, U., W. Glässer, H. Klapper, E. Weissbrodt, B. Eccarius, C. Kennedy, M. Schultze, K. Wendt-Potthoff, R. Frömmichen, P. Schreck \& G. Strauch. 1999. Strategies for remediation of former opencast mining areas in eastern Germany. In: Ascue, J.M. (Ed.), Environmental impacts of mining activities. Springer Berlin, Heidelberg, New York: 263-296.

Vietinghoff, H. 2002. Erste Erfahrungen mit der externen PElimination an einem polymiktischen Flachsee (Kleiner Seddiner See, Brandenburg). IGB-Workshop Seentherapie, Blossin, Abstracts.

Vietinghoff, H. 2001. Restaurierung des Kleinen Seddiner Sees durch externe Phosphatelimination - Projektdokumentation und erste Ergebnisse. UFO Atelier für Gestaltung und Verlag Allensbach, 249: 63 pp.

Zeman, A.J. \& Patterson, T.S. 1997. Preliminary results of demonstration capping project in Hamilton Harbour. Water Qual. Res. J. Canada, 32: 439-452. 